\section{ORIGTIAT COMUUUTICATIONS.}

\section{ATMOSPHERIC PHENOMENA IN RELATION TO THE PREVALENCE OF ASIATIC \\ CHOLERA.}

By J. A. HiNGeSton, Esq., Surgeon.

The Asiatic cholera seems to be associated with a particular state of air, in which it finds its nest for being engendered, fostered, and diffused. This state of the atmosphere is indicated by an overcast sky, a high barometer, a torpid mist, and, for the most part, though not invariably, a high temperature. The mercury in the barometer rises up to thirty inches, although, at the same time, the sky, instead of being Fair, as the instrument denotes, is, on the contrary, shrouded with a veil of clouds-cirro-strati, strati, or indolent cirro-cumuli, of a dull opaque colour. The wind subsides, a calm prevails, and a moisture bedews everything, both in-doors and out. This state of the atmosphere is so unmistakeable, that, when the disease has once broken out, we may be sure of hearing of its increase during the continuance of this sort of weather, and of its diminution the moment a change takes place, and the wind rises, and the barometer sinks, and the mist is dispersed. But the overcast sky and a high temperature are not so requisite to the propagation of the disease as the high barometer, the calm, and the mist. This disagreeable mist is most remarkable: it lies low, rolls off the higher places, descends into the vales and hollows, and settles in corners secluded from thoroughfare and draughts of air. Hence it has been inferred that cholera originates from sinks, sewers, etc.; but, as these offensive recesses are generally set apart by themselves in some enclosed spot, they only afford an undisturbed lodgment for the reception of the poisonous element already atloat in the air, where its malignity becomes condensed and concentrated. Accordingly, in tracing the history of the cholera, we find that it has prevailed chiefly in low, damp, confined localities; that it has appeared at all seasons of the year-midsummer, autumn, and spring, and even in the depth of winter, when the ground has been covered with snow; but that its intensity has been the greatest in the fall of the year, when the weather is moist, or in the middle of the year, when the summer has been wet. It was reported at St. Petersburgh, and, I think, at Moscow, during a hard winter; in this country, it broke out in the winter and spring in 18:32; in 1849, it prevailed during the summer and the beginning of the autumn; and this time, 1853, it was first reported in the month of Beptember.

As far back as 1832, Dr. Prout remarked the anomalous elevation of the barometer in connexion with the presence of Asiatic cholera; and at that time, i. e., more than twenty years ago, he attempted to account for it upon the hypothesis of the air being surcharged with a poisonous element of a ponderous nature. There was, he says (Stomach and Urinary Diseases, 3rd edition, 1841, p. 22), a positive increase in the weight of the atmospheric air, similar to what might be supposed to be produced by the diffusion of a very heavy gaseous principle through the lower regions of the atmospherc. His conclusion was, that the cause of the phenomenon in question, as well as of the cholera, was a poisonous body analogous to malaria, whose high specific gravity and feeble diffusive powers kept it near the earth's gravity and feeble ditfusive powly crept, particularly in low surface, along which it insens 9 th of February, 1832, the positive weight of the air suddenly appeared to rise above the usual standard. The apparatus cmployed was supposed to be out of order, but no error was detected; and the air continued to retain its augmented weight, with more or less obstinacy, for the space of six wecks longer. Now, on that particular day, when the barometer rose so suddenly, and, as it seemed, without a sufficient cause to explain its rise,on that particular day, the 9th of February, 1832, the first cases of epidemic cholera were reported in England. The wind, which had been previously westerly, veered round to the east, and remained pretty steadily in that quarter till the end of the month. In the sumwer of that same year, when cholera raged so severely for the first time in Great Britain, the barometer was high, the sky overcast, and the quantity of rain small. A calm prevailed. And, again, in the fatal summer of 1849 , I find, in my diary of the weather, that there had been upwards of sixty misty days between the lst of January and the 31st of August, $i$. e., one-fourth of the whole period; and that when the mortality was the highest, the weather was dull, thick, and close; the wind from the N.W., with dark masses of clouds, which went out to sea, like the smoke of a large furnace. The elevated position on which I dwell, and my frequent strolls in the surrounding country, gave me ample opportuvities of making these remarks with accuracy.

Subjoined is a diagram of the weather during the week that cholera was the worst at Neweastle this year; and what has already been said seems to be borne out, if not demonstrated, by this statistic report.

From Aurust 31st to September 16th, there were 295 fatal cases.

\begin{tabular}{|c|c|c|c|c|c|c|c|c|c|c|}
\hline 1853. & Wind. & Clouds. & Moisture. & Clear. & $\begin{array}{c}\text { Storm, fale, } \\
\text { calm. }\end{array}$ & Temp. & Therm. & $\begin{array}{l}\text { Ordinary } \\
\text { inortality. }\end{array}$ & Barometer. & $\begin{array}{l}\text { Fatul } \\
\text { cases. }\end{array}$ \\
\hline September $16 .$. & N.E.S.H.X. & $\begin{array}{l}\text { Bright } \\
\text { scud. }\end{array}$ & Moist. & $\begin{array}{l}\text { Ha\%y; } \\
\text { clear. }\end{array}$ & Breeze. & ('hilly. & $65+5 \pi$ & & $\begin{array}{c}\text { 29. Fair. } \\
\text { (below, but } \\
\text { rising.) }\end{array}$ & 101 \\
\hline $\begin{array}{l}\text { Septemler 17.. } \\
\text { (Full moon, } \\
10 \text { A.m.) }\end{array}$ & W.x.E. & Ditto. & Ditto. & Ditto. & Calm. & $\begin{array}{l}\text { Summer- } \\
\text { like, lint } \\
\text { chilly at } \\
\text { nierht. }\end{array}$ & $72+61$ & & 20 (rising ). & 101 \\
\hline Septemler 18. & s.w.s.w.s. & Ditto. & $\begin{array}{l}\text { Jitto; } \\
\text { drying. }\end{array}$ & Ditto. & Ditto. & Uitto. & $\tau 0+5 \tau$ & $\begin{array}{l}\text { 20!) (below } \\
\text { avernge). }\end{array}$ & $\begin{array}{c}30 \text { (above } \\
\text { Fuir } \\
\text { rising.) }\end{array}$ & $9: 3$ \\
\hline September 19.. & E.N.W.S.W.N. & $\begin{array}{l}\text { Ditto; over- } \\
\text { cast night. }\end{array}$ & Ditto. & Ditto. & Ditto. & & $71+57$ & & $\begin{array}{c}304 \\
\text { (nliove). }\end{array}$ & 94 \\
\hline September :20.. & x.w.s.w.s. & $\begin{array}{l}\text { Overeast ; } \\
\text { grey cirro- } \\
\text { strati; over- }\end{array}$ & Ditto. & $\begin{array}{l}\text { Thick; } \\
\text { dull. }\end{array}$ & Ditto. & Ditto. & $65+56$ & & $\begin{array}{l}30 \text { (fall- } \\
\text { ing). }\end{array}$ & 109 \\
\hline September $21 .$. & w.N.E.S.w. & $\begin{array}{l}\text { Cast night. } \\
\text { Ditto. }\end{array}$ & $\begin{array}{l}\text { Ditto; dew } \\
\text { at night. }\end{array}$ & Ditto. & $\begin{array}{c}\text { Breeze; } \\
\text { light air. }\end{array}$ & Chilly. & $6 i-51$ & & $\begin{array}{l}2 ! \text { (fall- } \\
\text { in }{ }^{2} \text { ). }\end{array}$ & 80 \\
\hline September $22 .$. & N.w.s. & $\begin{array}{c}\text { Broken } \\
\text { scud. }\end{array}$ & Ditto. & $\begin{array}{l}\text { Gloomy ; } \\
\text { light. }\end{array}$ & 1 gale s.w. & Ditto. & $68+55$ & & $\begin{array}{l}2 ! 9 \text { (be- } \\
\text { low). }\end{array}$ & 59 \\
\hline
\end{tabular}

The reports of the fatal cases, subjoined at the end of this paper, are from the Times. The account of atmospheric changes is from my private diary. It has been collated with those of the daily papers, and the variations are not great. The same weather seems to have prevailed throughout the country. In reporting the thermometer and barometer, the round 
numbers alone are stated. The mark + means above the average; the mark - belowe.

It has been said, that the velocity of the air is diminished one-half below its usual ratio; there is an upper, but no lower current of air; and the electricity of the air is negative, during the presence of cholera. I have no personal knowledge of the truth of these facts, but report them only as I have read them.

In this diagram, it appears that the cholera was the worst when the barometer was the highest and the atmosphere the calmest. There was on this occasion, as on the former ones, a certain grey mist, which painters express by the word sciembling. As the harometer fell, and the wind rose, and the lazy scud broke awily into clouds (cirrocumuli), the mortalitv fell at the same time from 109 to 8() and 59 respectively, in the course of a couple of days. But, what is most singular, is the fact that, on the present, as on the previous acesessions of the disease, the mortality from ordinitry ciuleses hit: been diminished; and, according to the Registrar-(ieneral's Report, it has been diminished on this particular occission two-tenths helow the average, i. e., 20 !) in the $1,(1 \times)(1)$ according to the corrected average. Although it is remarkable that the atmosphere is, during the prevalence of cholera, at once both calm and overcast, and the roads dry if not dusty, yet there is a sticky moisture pervaling everything. Ilousekecpers inform us that articles of diet become more quickly mouldy than usual. The appearance of the air is that of a marshy district, such as I hilve often witnessed on the low lands of Suffolk and Essex, and the neighlourhood of the Marsh Gate, Lambeth. But this miasmatic atmosphere, instead of being peculiar to those quarters where ague resides, seems to spread universally over the whole land assailed by cholera. 'I'he aftinity of the phenomena subsisting between cholera and ange is, to say the least of them, very striking. Diarrhue is the distinctive precursor or concomitant of each; and the collapse, so fatal in cholera, together with the rice-water eracuations, most likely of a poisonous quality, are exaggerated features of its congener, marsh fever. Again, both these discases haunt damp localitics, and exhibit themselves most virulently in the foulest corners; while each has the same tendency to degenerate into low typhus, hectic, and death, or a tedious recovery. This is more thin similarity - it is a coincident eventuality ; but repeated coincidence implies a law of commexion, perhaps identity.

One pathological remark of some importance ought not to be omitted. We are all of us aware that, during the blue stiuge of choleria, the urine is either suspemled or suppressed. But, during a cholerice period, there is also reigning an epilemic diathesis alverse to the healthy action of the kidneys. It is of the low kind, such as is termed cesthenir: : in plain worls, it is a wealiness of the kidneys. "' The first circumstance that attricted my notice," says Dr. Prout, op. cil., " "ffter the prevalence of Asiatic cholera, wat the disappearance of these (the common lateritious) serliments from the urine. The alsence of these sediments wats at first considered to be aceidental ; lut when, day after dav, the same occurrence took place, I was induced to induire altentively int, the circunstance, with the view, if posilile, of aseertaining the reason. On closer inspection, it was found that the urine of ererv individual examinel, whether in apparent health or otherwise, not only presenter the sams alvence of seliment, but also assumed that peculiar appearance, which I had been accustomed to consider as characteristic of the presence of oxalic acirl. I likewise noticel," he continues, "an unusually aciel state of the saliva, and of the cutaiteous exhalations, such as 1 had never, inleed, before noticel, exeept in the last stages of chronic diseases, or in malarious affections."

Nothing can be nore correct than these remarks. I should like to learn whether the experience of others, who have paicl atcention to renal disorders, agrees with mine on the present occasion ; which is, that the present renal diathesis is more phosphatic than oxalic? What Dr. Prout says in respect of the condition of the urine being that of malarious affections, is very just. In agueish districts, the urine of most persons is disposed to be pale, copjous, and of a low specific gravity; and the absence of the lateritious sediments is so well known, that their reappearance is hailed as a good sign, and looked upon as a criterion of the ague fits having come to their end. This again is another striking analogy subsisting between ague and cholera.

\section{“the cholera. (FROX the boARd ON heALTH.)} Newcastue, Sept. 22.

Deaths. $\left\{\begin{array}{llllll}\text { Cholera - } & - & - & - & - & 59 \\ \text { Diarrhoid } & - & - & - & - & 1\end{array}\right.$

"Thus, the total number of deaths from cholera and diarrhoea in Newcastle during the present outbreak has been 995 .

"In the same period (viz.the first twenty-two days) during the prevalence of epidemic cholera there in 1831-2, the number of deaths was 161 .

\section{"Newcastue, Friday Morning.}

"The weather is still most farourable, and our people are hecoming more reassured. The deaths yesterday were sixty. In Gateshead only eight. Our local papers this morning give a fearful middle-class obituary. The Chronicle has above three-fourths of a column of deaths in Newcastle, nearly all middle-class people. We have had the cholera amonc us three weeks and one day, and the deaths have been, in Newcastle and the Gateshead Union, the appalling number of 1,318 . The following are the statisties of the progress of the disease in Newcistle, made up from the registrar's returus :-

$$
\begin{aligned}
& \text { “ August } 31 \text { to Sept. 15 } \quad \begin{array}{ccccccc} 
& \text { Chwlera. } & 295 & \ldots & 20 & \ldots & 315
\end{array}
\end{aligned}
$$

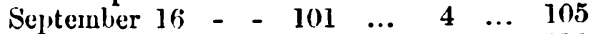

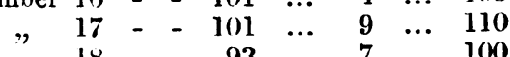

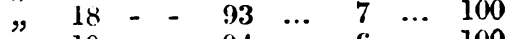

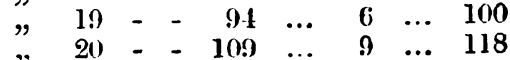

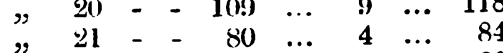

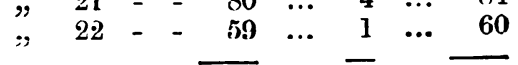

$$
\begin{aligned}
& \text { Total - } \overline{932} \quad \overline{60} \quad 992
\end{aligned}
$$

"The following table shows the amount of mortality from cholera and diarrhou in the different parishes:-

\begin{tabular}{|c|c|c|c|c|c|c|c|c|c|c|}
\hline & \multicolumn{2}{|c|}{$\begin{array}{c}\text { All } \\
\text { Saints: }\end{array}$} & \multicolumn{2}{|c|}{$\begin{array}{l}\text { St. Ni- } \\
\text { cholas. }\end{array}$} & \multicolumn{2}{|c|}{$\begin{array}{l}\text { ic An- } \\
\text { drew's. }\end{array}$} & \multicolumn{2}{|c|}{ Westgnte. } & \multicolumn{2}{|c|}{ Byker. } \\
\hline & iflol. & Dhar. & ('hol. & Diar & Chol. & Diar & Chol. & Diar. & Chol. & Diar. \\
\hline \multirow{9}{*}{ 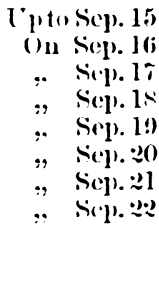 } & $\boldsymbol{\alpha \tau}$ & ;3 & איא & \pm & 40 & 5) & ה) & 8 & 16 & - \\
\hline & 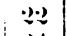 & - & $: 31$ & 1 & $10 ;$ & 1 & 26 & $\because$ & (j) & - \\
\hline & 21 & $\because$ & $: 3 \cdot 3$ & 1 & 18 & 1 & 16 & 3 & 12 & 1 \\
\hline & $: 3()$ & - & 14 & $\because$ & 1:5 & - & 26 & 4 & $!$ & 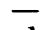 \\
\hline & $2 \pi$ & $:$ & $\because 1$ & 3 & 14 & - & 17 & $: 3$ & 1:! & 1 \\
\hline & $3: 3$ & - & 2 & 1 & 17 & 4 & $\because 2$ & 6 & 15 & - \\
\hline & $: 3$ & - & 17 & - & 1:3 & - & 12 & \pm & ! & - \\
\hline & 15) & $\cdots$ & 15 & 1 & $1: 3$ & - & $1 \%$ & - & 4 & - \\
\hline & $\because(i)$ & $\tau$ & 210 & $1: 3$ & 112 & 11 & $1 ! 5$ & $31)$ & הi: & $\because$ \\
\hline
\end{tabular}

"We have lost two medical men, Mr. Irons, surgeon, and 1)r. Malcolm, the former gentleman falling a martyr to his duty as a union surgeon. 'The vicar, the Rev. C. Moody, has opened kitchens for the distribution of beef-tea and boiled rice, in the parishes of St. Nicholas, St. John, and All Saints. 'They are open to persons of all classes and denominations; and the benevolent throughout the country would serve the cause of humanity and the poor by sending subscriptions to the reverend gentleman. The Ordnance tents will be opened on the moor to-day for such of the poor as are inclined to leave the infected districts. There is also a house of refuge on the New-road. Eight deaths have occurred in the gaol ; in fact, no part of the town has escaped. The epidemic has been bad in Hexham. The condition of that town is unwholesome, though its 
situation is the garden of the north of England. Before the appearance of the cholers, there was a stout fight for the Public Health Act, and the obstructives were beaten. Some of the medical men opposed the introduction of the act. Mr. Fairbridge, surgeon, has died at Hexham. There are thirteen deaths in that town. The cholers has visited nearly all the villages by the side of the Tyne. There have been four deaths at Howdon and Willington; four at Walker; two at Carville; and several at the Felling. A very interesting and reassuring fact was related to me this morning by a gentleman from Jarrow, a considerable manufacturing village by the side of the Tyne. An old woman who had been to Newcastle and got rather tipsy, on reaching the village ate some half-cooked herring, was attacked, and died after a short illness. Her husband died a few days after. A board of health was immediately formed, under the presidency of the resident clergyman, a " house to house" visitation was instituted, nuisances were removed, etc.; and though there have been between two and threc hundred cases of diarrhcea (promptly attended to by the medical officers), there has not been it single death, except those of the two old persons mentioned

"The epidemic has been very fatal in a village named Whorlton, near Morpeth. Morpeth seems to have escaped." (From the Times.)

Brighton, Otwher 1553.

\section{CASE OF POISONING BY CREASOTE; WITH REMARKS.}

By J. D. JEFFERY, Esq., Surgeon.

Case. August 29, 1853, I was called up in the night to see Mrs. B., her husband informing me that "she was in a very strange way, and he thought she was dying."

I found a young woman about twenty-four years of age, in bed. She was insensible; her countenance very pale; frothing at the mouth; pupil quite dilated; pulse regular, rather full, about 80 ; the circulation seemed undisturbed. Every few minutes there was violent urging, nothing but saliva resulting. The stomach had been emptied by vomiting before I came. She had apparently severe paroxysms of pain on the right side of the face, to which she violently applied her hand; then again became prostrate. Her breath smelt strongly of creasote. A molar tooth on the right side of the lower jaw had a large cavity in it.

I endearoured to rouse her by washing the face and temples with cold vinegar and water; and, as the paroxysmis of pain seemed referrible to the liseased tooth, I fetched an instrument and removed it. She seemed scarcely to feel the operation; but the pain, after a short time, appeared to have left her. In the course of an hour she improved, and became partially sensible.

I administered nothing but a mixture of sesquicarbonate of soda and water. The next morning I found her better, but pale and weak; the pupils of the eyes were still much dilated, and vision was imperfect, which continued for several days.

The patient's own account of the matter and of her sensations, which I took down on her recovery, perhajs may not be uninteresting :-

"Whilst in the act of putting a piece of lint saturated with creasote into my tooth, it slipped, and I accidentally swallowed it. In a few minutes (much less than a quarter of an hour), I felt myself going very low. My eyesight went from me; giddiness came on; and everything looked of a dark blue, even the candles, my husband, and everything. I felt a dreadful burning at my chest. I wanted water to quench the burning at my lungs. I vomited, and brought up the piece of lint with some food. I had great pain at the front of my head, and felt numbed all over. The pain at my chest continued, and my eyesight was imperfect for three or four days. I did not see plain until Friday (Sept. 2nd). I did not know my tooth had been taken out."
I think it right to place this case on record. I am not acquainted with a similar one. I should think there could not have been more than five or six drops of creasote on the lint.

I mentioned this case to Dr. Cormack soon after its occurrence, when he observed that the case was remarkable from the characteristic effects of poisoning by creasote having been produced by a dose not much larger than he was in the nabit of prescribing with great adrantage in cases of choleraic serous purging. I find upon referring to Dr. Cormack's account of experiments which he performed on animals in 1836 , with creasote, the following remarks by that gentleman:-

"From all these experiments, the poisonous effects of creasote appear to bear a very striking resemblance to those of prussic acid. Like the latter, creasote acts toxicologically, either by stopping the heart, or by directly affecting the brain alone-just as the dose may be larger or smaller, or according to the manner in which the substauces are introduced into the system. Another very striking point of resemblance between prussic acid and creasote, is the remarkable and almost specific power which they both posscss of arresting vomiting, especially if it be unconnected with organic disease." (Cormack on (reasote, p. 79.)

In another part of the same work, Dr. Cormack remarks : "In medicine, creasote may be used with great advantage as a sedative or anodyne. To produce such effects, it is given in diseases of the heart, pulmonary complaints, vomiting, and to allay the pain of cancer, etc. A patient under Dr. Shortt, in the Royal infirmary of Edinburgh, afflicted with cancer of the stomach, derived relief from pain in ten minutes after taking a dose of fifteen drops. When its sedative or anodyne action is wished speedily, the object is best attained by inhaling its rapours." (p. 93.)

From the above extracts, and from the fact of my patient not knowing when her tooth was taken out, clear evidence is afforded of the ancusthetic powers of creasote. It may be remarked that chloroform, the popular anxithetic agent of the dry, is, like creasote and prussic acid, one of the most efficient remedies for vomiting: and that the medicinal as well as the poisonous effects of these three agents possess many striking resemblances.

Iowesmore House, Horecster, Oct. 1\%, 1853.

\section{ANOTHLR SINGULAR CASE OF ALOPECIA.}

\section{by GLORGE STLWYN MORRIS, Fisq.}

IT may be interesting to Dr. Barclay's readers in the last number of the Aswionatios Jouknat (p. 902), to hear of another singular instance of complete alopecia; and as I have a case of precisely the same nature, I subjoin the following notes.

S. A. W. is a young woman aged 20 , residing in this place. Her parents, so far as I can discover, were free from syphilis and scrofula, and were in all respects perfectly healthy people. S. A. W. has not a particle of hair on any part of her hody. I have examined her all over; and have only been able to find a slight appearance of down on certain purts of her skin. She began to lose her hair, without any assignable causc, when between cight and nine years of are. She tells me that her sister, a child between six and seven years old, is in exactly the same predicament.

I have not yet commenced the treatinent; but my present intention is to follow the plan which Dr. Barclay adopted in his case.

Sydenhais, Kent, October $1 \%, 1 \times 53$.

[Another case of complete alopecia reached us as we were going to press. E.D.] 